\title{
Collimonas arenae sp. nov. and Collimonas pratensis sp. nov., isolated from (semi-)natural grassland soils
}

\author{
Correspondence \\ W. de Boer \\ w.deboer@nioo.knaw.nl
}

\author{
S. Höppener-Ogawa, ${ }^{1}$ W. de Boer, ${ }^{1}$ J. H. J. Leveau, ${ }^{1}$ J. A. van Veen, ${ }^{1}$ \\ E. de Brandt, ${ }^{2}$ E. Vanlaere, ${ }^{2}$ H. Sutton, ${ }^{3}$ D. J. Dare ${ }^{3}$ and P. Vandamme ${ }^{2}$
}

${ }^{1}$ Netherlands Institute of Ecology (NIOO-KNAW), Centre for Terrestrial Ecology, Boterhoeksestraat 48, 6666 GA Heteren, The Netherlands

${ }^{2}$ Laboratory for Microbiology, Ghent University, B-9000 Ghent, Belgium

${ }^{3}$ Manchester Metropolitan University, The Heath Business \& Technical Park, Runcorn, Cheshire, UK
The genus Collimonas was described on the basis of 22 isolates that were obtained from slightly acidic dune soils from the Wadden island Terschelling in the Netherlands (De Boer et al., 2001, 2004). Collimonas strains have the interesting ability to grow at the expense of living fungal hyphae (mycophagy), albeit under laboratory conditions (De Boer et al., 2001, 2004). The taxonomy of these bacteria was examined using genomic fingerprinting (BOX-PCR), sequencing of 16S rRNA genes and physiological characterization, which revealed four clusters of strains (De Boer et al., 2004). So far, only cluster C strains have been formally classified, as the novel species Collimonas fungivorans. The present investigation was designed to establish the taxonomic position of the three

Abbreviation: MALDI-TOF, matrix-assisted laser desorption ionization time-of-flight.

The GenBank/EMBL/DDBJ accession numbers for the 16S rRNA gene sequences of strains LMG $23964^{\top}$ and LMG $23965^{\top}$ are AY281146 and AY281137, respectively. Those for other strains included in this study are listed in Table 1.

Detailed DNA-DNA hybridization results are available as supplementary material with the online version of this paper. other clusters and of 26 new Collimonas isolates from different types of soils in the Netherlands (Table 1).

The new Collimonas isolates were taken from chitin agar enumeration plates of soil samples of eight (semi-)natural grasslands and a heathland in the Netherlands, as described previously (Höppener-Ogawa et al., 2007) (Table 1). Based on colony morphology in combination with Collimonasspecific restriction fragment length polymorphism analysis of $16 \mathrm{~S}$ rRNA genes, these 26 isolates were identified as Collimonas isolates (Höppener-Ogawa et al., 2007). All isolates were stored at $-80{ }^{\circ} \mathrm{C}$ and maintained on 10 -folddiluted tryptone soy broth (TSB) agar for routine culturing. The 10-fold-diluted TSB agar contained $\left(1^{-1}\right) 1 \mathrm{~g} \mathrm{KH}_{2} \mathrm{PO}_{4}$, $5 \mathrm{~g} \mathrm{NaCl}, 3 \mathrm{~g}$ TSB (Oxoid) and $20 \mathrm{~g}$ agar. Media were adjusted to $\mathrm{pH} 6.5$ with $1 \mathrm{M} \mathrm{NaOH}$ before autoclaving.

Repetitive sequence-based PCR profiles of the isolates were determined using the BOX-A1R primer, as described by Rademaker et al. (1997). Colony PCR was performed using fresh colonies that were taken from 10-fold-diluted TSB agar after $24 \mathrm{~h}$ of incubation (Rademaker et al., 1997). Visual comparison of the banding profiles and UPGMA clustering of strains using Pearson's product-moment correlation coefficients in the Bionumerics version 3.5 
Table 1. Strains used in this study and their origins

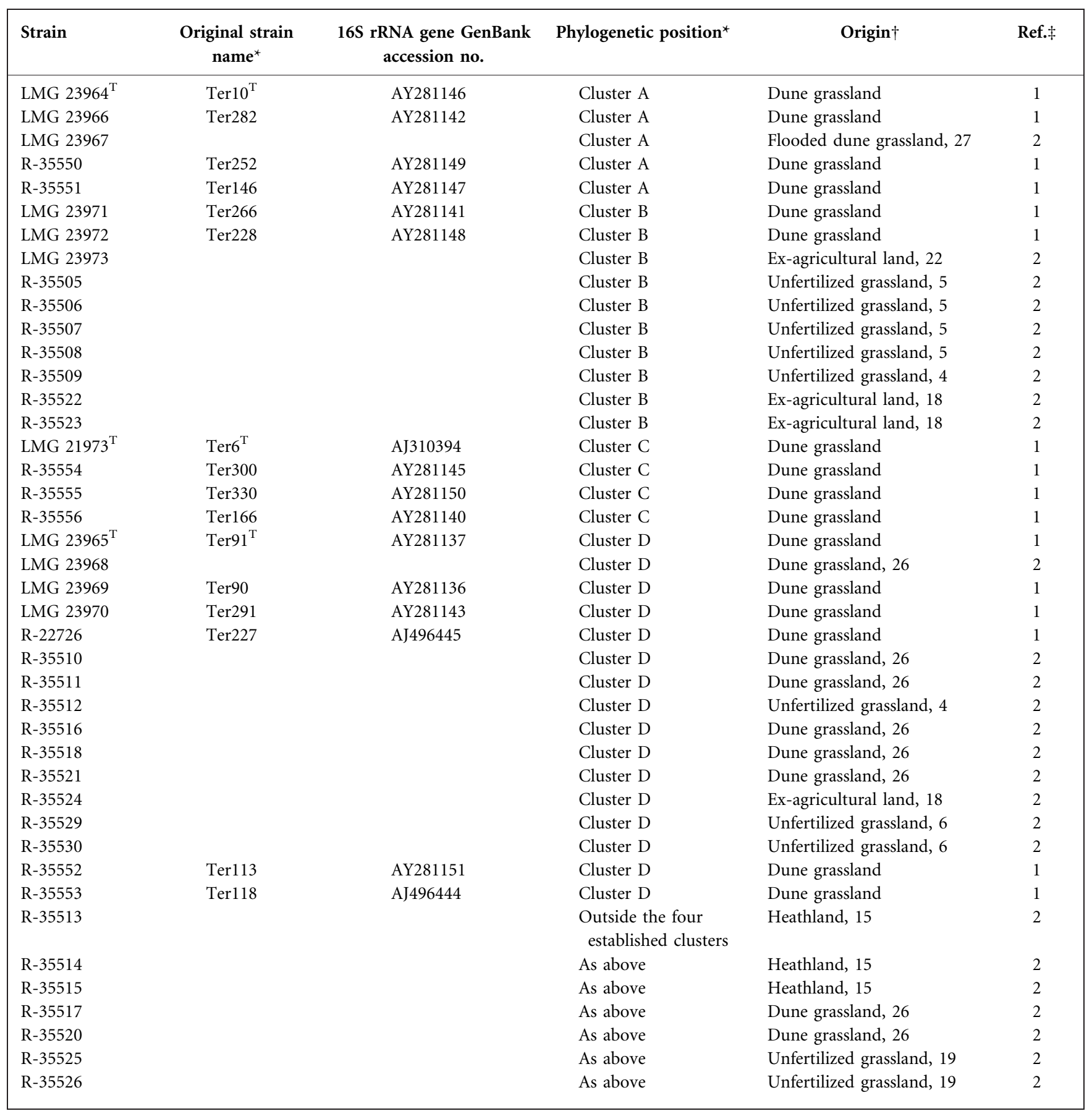

${ }^{\star}$ From De Boer et al. (2004).

$\dagger$ Sites from which Ter strains were isolated are described by De Boer et al. (1998); numbers refer to sites described by Höppener-Ogawa et al. (2007).

¥References: 1, De Boer et al. (2004); 2, Höppener-Ogawa et al. (2007).

software package revealed that the majority $(n=18)$ of the new isolates fell within clusters $B$ and $D$ described previously (De Boer et al., 2004). Only one of the new isolates fell in cluster $\mathrm{A}$. The remaining seven isolates occupied distinct positions in the dendrogram (Fig. 1).
Isolates grown for $48 \mathrm{~h}$ at $28{ }^{\circ} \mathrm{C}$ on phosphate-buffered nutrient agar ( $\mathrm{pH} 6.8$ ), which contained $\left(\mathrm{l}^{-1}\right) 0.45 \mathrm{~g}$ $\mathrm{KH}_{2} \mathrm{PO}_{4}, 2.39 \mathrm{~g} \mathrm{Na}_{2} \mathrm{HPO}_{4} \cdot 12 \mathrm{H}_{2} \mathrm{O}, 2.39 \mathrm{~g}$ nutrient agar (Oxoid) and $20 \mathrm{~g}$ agar, were subjected to SDS-PAGE analysis of whole-cell proteins. One-dimensional analytical 


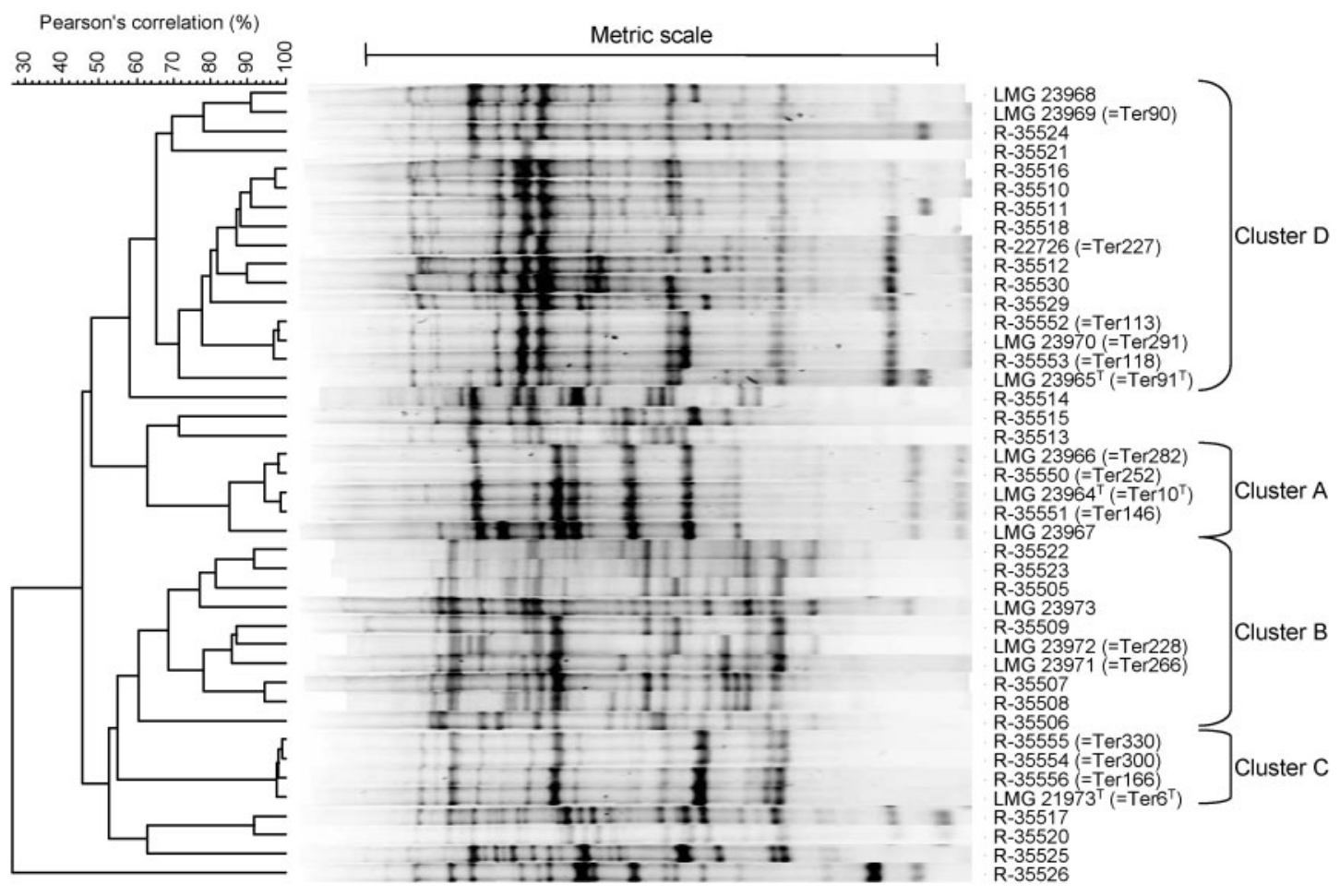

Fig. 1. Grouping of normalized digitized BOX-PCR fingerprint patterns of the 42 Collimonas isolates in a dendrogram based on UPGMA clustering of Pearson's correlation similarity coefficients.

SDS-PAGE was performed with a $12 \%$ separating gel and a $5 \%$ stacking gel using a previously described protocol (Pot et al., 1994). Analysis of the whole-cell protein patterns supported the clustering result of the BOX-PCR fingerprint patterns (results not shown).

Twenty isolates (Fig. 2) were analysed by matrix-assisted laser desorption ionization time-of-flight mass spectrometry (MALDI-TOF MS) of intact cells. Bacterial cultures were grown and maintained on Columbia blood agar, containing $5 \%(\mathrm{v} / \mathrm{v})$ sheep blood. Incubation was standardized to $24 \mathrm{~h}$ and strains were grown aerobically at $28{ }^{\circ} \mathrm{C}$. All strains were subcultured three times prior to MALDI-TOF analysis. Sample and target plate preparation, data acquisition using a M@LDI Linear TOF Mass Spectrometer [Waters Corporation (Micromass)] and data processing (with the aid of the MassLynx/MicrobeLynx ${ }^{\mathrm{TM}}$ software; Micromass) were performed as described previously (Keys et al., 2004). After cluster analysis of the spectral profiles (Fig. 2), 17 isolates formed four clusters, confirming results obtained by BOX-PCR fingerprinting and whole-cell protein electrophoresis (Fig. 1 and data not shown). The mass range $m / z$ 2500-7500 Da contained the most discriminatory peaks, whereas the low $(\mathrm{m} / z$ 500$2500 \mathrm{Da})$ and high $(\mathrm{m} / z$ 7500-10000 Da) mass ranges were very similar (data not shown). Strain R-35526, which occupied a distinct position in the BOX-PCR analysis (Fig. 1), and strains LMG 23973 (cluster B) and R-35529 (cluster D) represented a fifth cluster in the numerical analysis of the MALDI-TOF MS profiles.

To analyse whether the different clusters represent distinct species, DNA-DNA hybridization experiments were performed using a modification of the microplate method (Ezaki et al., 1989) as described by Willems et al. (2001). Genomic DNA was prepared as described by Marmur (1961). A hybridization temperature of $45^{\circ} \mathrm{C}$ was used. Isolates with different DNA fingerprints (Fig. 1) were selected as representatives of each cluster and were subsequently hybridized with each other (Supplementary Table S1, available in IJSEM Online). The cluster B strains (LMG 23971 and LMG 23973) showed DNA-DNA hybridization values of 75 and $70 \%$, respectively, towards C. fungivorans LMG $21973^{\mathrm{T}}$ (cluster C). Strains LMG 23968 and R-35524 exhibited DNA-DNA hybridization values towards strain LMG $23965^{\mathrm{T}}$ of 75 and $87 \%$, respectively, indicating that these three cluster $\mathrm{D}$ strains represent a single genospecies. All DNA-DNA hybridizations between strains representing distinct clusters yielded low to intermediate values in the range of 31 to $64 \%$ (Supplementary Table S1). These data indicate that the cluster $\mathrm{B}$ isolates belong to $C$. fungivorans, whereas the cluster $\mathrm{A}$ and $\mathrm{D}$ isolates represent two novel genospecies. The DNA $\mathrm{G}+\mathrm{C}$ contents of $C$. fungivorans LMG $21973^{\mathrm{T}}$ and strains LMG $23964^{\mathrm{T}}$, LMG $23965^{\mathrm{T}}$ and LMG 23971, as determined by HPLC (Mesbah et al., 1989), were 59, 57, 59 and $59 \mathrm{~mol} \%$, respectively. 


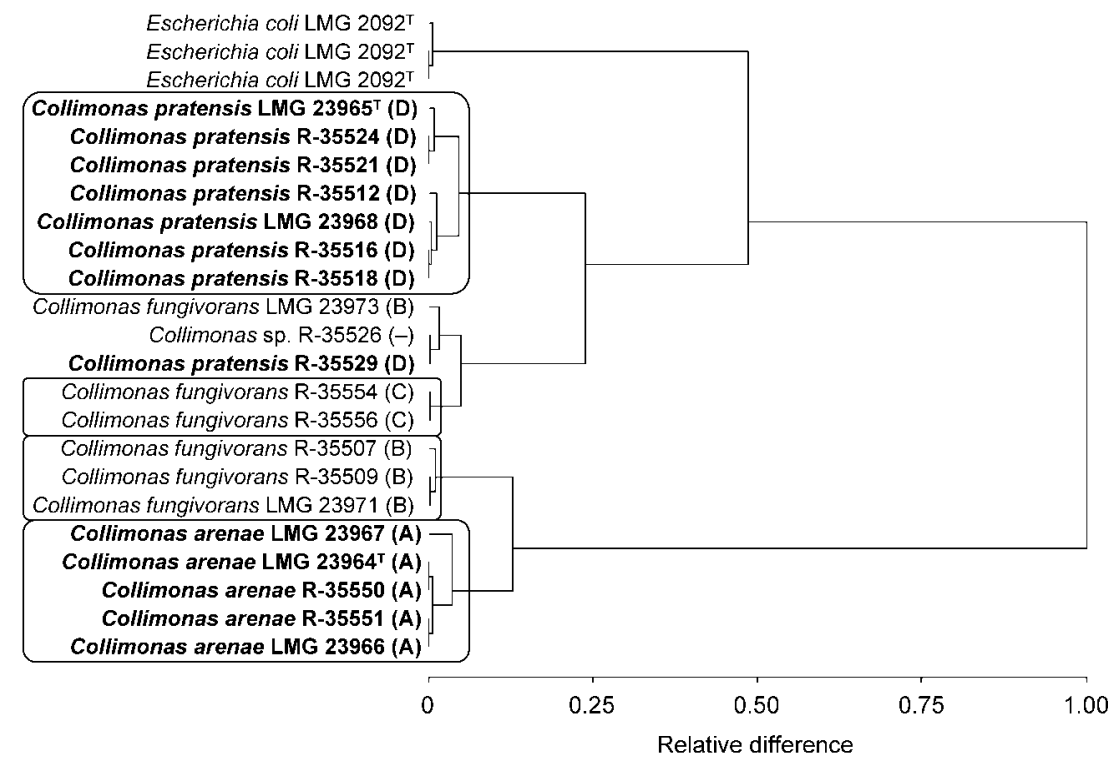

Fig. 2. Numerical analysis of MALDI-TOF MS spectral patterns generated using the MicrobeLynx ${ }^{\mathrm{TM}}$ software package. Cluster A-D strains are shown in boxes. Three repeat measurements of Escherichia coli LMG $2092^{\top}$ (included as a positive control) are shown to illustrate the reproducibility of the profiles.

Biochemical tests were performed for isolates representing clusters A (LMG 23964 ${ }^{\mathrm{T}}$, LMG 23966, LMG 23967, R35550 and R-35551), B (LMG 23971, LMG 23972, LMG 23973, R-35508 and R-35509), C (LMG 21973 ${ }^{\mathrm{T}}$, R-35554, R-35555 and R-35556) and D (LMG 23965 ${ }^{\mathrm{T}}$, LMG 23968, R-35510，R-35511，R-35512，R-35516，R-35518，R-35524, R-35529 and R-35530). Strains were examined for catalase and oxidase activities (King et al., 1954). The ability to oxidize various carbon sources was tested using Biolog GN plates following the manufacturer's instructions (Table 2). Detection of enzyme activities was done using the API 20NE and API ZYM microtest systems (bioMérieux) according to the manufacturer's instructions (Table 2). The presence of the nifH gene was examined as described by Rosch \& Bothe (2005). Test results and differential biochemical characteristics are listed in Table 2 and in the species descriptions.

Cellular fatty acid contents reported by De Boer et al. (2004) could not be used to distinguish clusters within the genus Collimonas (results not shown).

In summary, data from the present study demonstrate that cluster B isolates belong to C. fungivorans and that cluster A and D isolates represent two novel Collimonas species, which can be differentiated from each other and from $C$. fungivorans by means of genotypic (Fig. 1; De Boer et al., 2004) and phenotypic (Table 2) characteristics. We propose to classify the cluster A and D strains formally into the novel species Collimonas arenae sp. nov. and Collimonas pratensis sp. nov., respectively. The taxonomic status of seven isolates (Table 1) identified as members of the genus Collimonas by their ability to clear colloidal chitin and by their Collimonas-specific $16 \mathrm{~S}$
rRNA restriction patterns (Höppener-Ogawa et al., 2007) needs further study. These strains may represent additional species within the genus Collimonas. The data obtained by MALDI-TOF MS indicate that this novel technology is useful for the rapid identification of Collimonas strains at the genus and species levels, although two of 20 isolates examined clustered aberrantly.

\section{Description of Collimonas arenae sp. nov.}

Collimonas arenae (a.re'nae. L. gen. n. arenae of sand, referring to the isolation of strains from sandy soil).

After 2 days of incubation at $20{ }^{\circ} \mathrm{C}$ on 10 -fold-diluted TSB agar, colonies are flat, translucent and whitish with a yellowish central part and 3-7 $\mathrm{mm}$ in diameter with a granular-structured periphery (colony type II) (De Boer et al., 2004). Cells exhibit oxidase and weak catalase activity. The nifH gene, required for nitrogen fixation, is not detected by PCR-based methods. Carbon-source utilization is presented in Table 2. C. arenae can be differentiated from $C$. fungivorans and $C$. pratensis by the inability to assimilate trehalose and the lack of $\beta$-galactosidase activity.

The type strain is Ter $10^{\mathrm{T}} \quad\left(=\mathrm{LMG} 23964^{\mathrm{T}}=\mathrm{CCUG}\right.$ $54727^{\mathrm{T}}$ ). It has a DNA G $+\mathrm{C}$ content of $59 \mathrm{~mol} \%$ and was isolated from (semi-)natural grassland in the Netherlands in 1998.

\section{Description of Collimonas pratensis sp. nov.}

Collimonas pratensis (pra.ten'sis. L. fem. adj. pratensis growing in a meadow, referring to the isolation of strains from grassland). 
Table 2. Physiological characterization of C. fungivorans and the novel strains

Clusters B and C correspond to C. fungivorans. Clusters A and D correspond to the novel species $C$. arenae sp. nov. and C. pratensis sp. nov., respectively. + , Positive; $\mathrm{w}$, weakly positive; - , negative; $d$, strain-dependent, with reaction for the type strain in parentheses. All strains characterized in this study were positive for utilization of bromosuccinic acid, D-fructose, D-galactose, $\alpha$-D-glucose ${ }^{a_{\star}}$, L-asparagine, D-glucuronic acid, L-glutamic acid, D-mannitol ${ }^{a}, \beta$-hydroxybutyric acid and malic $\operatorname{acid}^{a}$. All strains were also positive for production of alkaline phosphatase ${ }^{b}$, leucine arylamidase $^{b}$, acid phosphatase $^{b}$ and naphthol-AS-BI-phosphohydrolase ${ }^{b}$. All strains were negative for utilization of i-erythritol, melibiose, $\alpha$-cyclodextrin, methyl $\beta$-D-glucoside, itaconic acid, raffinose, thymidine, gentiobiose, L-rhamnose, L-phenylalanine, phenylethylamine, putrescine, sucrose, 2,3-butanediol, adonitol, $\alpha$-D-lactose, lactulose, maltose, sebacic acid, DL-carnitine, glucose 1-phosphate and $\gamma$-hydroxybutyric acid. All strains were also negative for production of cystine arylamidase ${ }^{b}, \beta$ glucuronidase $^{b}, \alpha$-glucosidase ${ }^{b}, \alpha$-fucosidase ${ }^{b}$, assimilation of adipic $\operatorname{acid}^{a}$ and phenylacetic acid ${ }^{a}$, indole production ${ }^{a}$, D-glucose fermentation $^{a}$ and arginine dihydrolase ${ }^{a}$. All strains were weakly positive for production of esterase ${ }^{b}$, esterase lipase ${ }^{b}$ and valine arylamidase ${ }^{b}$.

\begin{tabular}{|c|c|c|c|}
\hline Characteristic $^{\star}$ & Clusters B and C & Cluster A & Cluster D \\
\hline \multicolumn{4}{|l|}{ Assimilation of: } \\
\hline Urocanic acid & $\mathrm{d}(+)$ & - & $\mathrm{d}(+)$ \\
\hline Succinamic acid & - & $\mathrm{d}(-)$ & $\mathrm{d}(\mathrm{w})$ \\
\hline Hydroxy-L-proline & - & - & $\mathrm{d}(-)$ \\
\hline Inosine & $\mathrm{d}(+)$ & + & $\mathrm{d}(+)$ \\
\hline L-Fucose & + & + & $\mathrm{d}(+)$ \\
\hline Uridine & + & + & $\mathrm{d}(+)$ \\
\hline Formic acid & + & + & $\mathrm{d}(+)$ \\
\hline L-Ornithine & - & $\mathrm{d}(-)$ & - \\
\hline$\alpha$-Ketovaleric acid & $\mathrm{d}(-)$ & $\mathrm{d}(-)$ & - \\
\hline D-Alanine & $\mathrm{d}(\mathrm{w})$ & $\mathrm{d}(-)$ & - \\
\hline D-Galacturonic acid & - & $\mathrm{d}(+)$ & $\mathrm{d}(-)$ \\
\hline L-Proline & + & + & $\mathrm{d}(+)$ \\
\hline myo-Inositol & + & + & $\mathrm{d}(+)$ \\
\hline D-Gluconic acid & + & $\mathrm{d}(+)$ & $\mathrm{d}(+)$ \\
\hline Malonic acid & $\mathrm{d}(-)$ & - & - \\
\hline 2-Aminoethanol & $\mathrm{d}(+)$ & - & - \\
\hline Trehalose & + & - & + \\
\hline D-Glucosaminic acid & + & $\mathrm{d}(+)$ & $\mathrm{d}(+)$ \\
\hline Propionic acid & $\mathrm{d}(+)$ & + & $\mathrm{d}(\mathrm{w})$ \\
\hline D-Serine & $\mathrm{d}(\mathrm{w})$ & - & - \\
\hline L-Aspartic acid & + & + & $\mathrm{d}(+)$ \\
\hline Glycerol & + & + & $\mathrm{d}(+)$ \\
\hline L-Arabinose ${ }^{a}$ & $\mathrm{~d}(+)$ & + & $\mathrm{d}(+)$ \\
\hline Xylitol & $\mathrm{d}(+)$ & - & $\mathrm{d}(+)$ \\
\hline$\alpha$-Hydroxybutyric acid & $\mathrm{d}(\mathrm{w})$ & + & $\mathrm{d}(-)$ \\
\hline D-Saccharic acid & + & + & $d(+)$ \\
\hline DL- $\alpha$-Glycerol phosphate & - & $\mathrm{d}(-)$ & $\mathrm{d}(-)$ \\
\hline D-Arabitol & $\mathrm{d}(+)$ & + & + \\
\hline Cellobiose & $\mathrm{d}(-)$ & - & - \\
\hline Succinic acid & + & + & $\mathrm{d}(+)$ \\
\hline Glucose 6-phosphate & - & $\mathrm{d}(+)$ & $\mathrm{d}(-)$ \\
\hline
\end{tabular}

\begin{tabular}{|c|c|c|c|}
\hline Characteristic $^{*}$ & Clusters B and C & Cluster A & Cluster D \\
\hline D-Mannose ${ }^{a}$ & $\mathrm{~d}(+)$ & $\mathrm{d}(\mathrm{w})$ & $\mathrm{d}(+)$ \\
\hline Potassium gluconate $^{a}$ & $\mathrm{~d}(\mathrm{w})$ & $\mathrm{d}(+)$ & $\mathrm{d}(\mathrm{w})$ \\
\hline Capric $\operatorname{acid}^{a}$ & - & $\mathrm{d}(-)$ & - \\
\hline Trisodium citrate ${ }^{a}$ & $\mathrm{~d}(+)$ & $\mathrm{d}(-)$ & + \\
\hline \multicolumn{4}{|l|}{ Production of: } \\
\hline Lipase $^{b}$ & $\mathrm{w}$ & $\mathrm{d}(\mathrm{w})$ & + \\
\hline Trypsin $^{b}$ & $\mathrm{~d}(+)$ & $\mathrm{d}(\mathrm{w})$ & $\mathrm{d}(\mathrm{w})$ \\
\hline$\alpha$-Chymotrypsin ${ }^{b}$ & $\mathrm{~d}(+)$ & $\mathrm{d}(\mathrm{w})$ & $\mathrm{d}(\mathrm{w})$ \\
\hline$\alpha$-Galactosidase ${ }^{b}$ & - & - & $\mathrm{d}(\mathrm{w})$ \\
\hline$\beta$-Galactosidase ${ }^{b}$ & + & - & + \\
\hline$\alpha$-Mannosidase ${ }^{b}$ & $\mathrm{~d}(\mathrm{w})$ & - & $\mathrm{d}(-)$ \\
\hline$\beta$-Glucosidase ${ }^{b}$ & $\mathrm{~d}(-)$ & - & $\mathrm{d}(-)$ \\
\hline Protease $^{a}$ & $\mathrm{~d}(+)$ & $\mathrm{d}(+)$ & $\mathrm{d}(\mathrm{w})$ \\
\hline
\end{tabular}

${ }^{\star}$ Results were obtained with the Biolog GN test system unless indicated as follows: $a$, API 20NE; $b$, API ZYM.

After 2 days of incubation at $20{ }^{\circ} \mathrm{C}$ on 10 -fold-diluted TSB agar, colonies are small, glossy and whitish, 1-3 mm in diameter (colony type III) (De Boer et al., 2004). One isolate (R-35518) produces a purple pigment, which deviates from the general genus description (De Boer et al., 2004). Cells exhibit oxidase but no or weak catalase activity. The nifH gene required for nitrogen fixation is not detected by PCR-based methods. Carbon-source utilization and enzyme production are given in Table 2 and indicate a strong phenotypic flexibility within the species. C. pratensis can be differentiated from $C$. fungivorans by its colony morphology and its pronounced lipase activity. Additionally, comparison between the type strains of $C$. pratensis and $C$. fungivorans shows more differences in use of carbon substrates and production of enzymes (Table 2). Differentiation of $C$. pratensis from C. arenae is discussed above.

The type strain is $\operatorname{Ter}^{\mathrm{T}}{ }^{\mathrm{T}}\left(=\mathrm{LMG} 23965^{\mathrm{T}}=\mathrm{CCUG}\right.$ $54728^{\mathrm{T}}$ ), which has a DNA G $+\mathrm{C}$ content of $59 \mathrm{~mol} \%$ and was isolated from (semi-)natural grassland in the Netherlands.

\section{Acknowledgements}

This is publication 4131 of the Netherlands Institute of Ecology (NIOO-KNAW). The funding of the research of S.H.-O. by the Netherlands Organization for Scientific Research (NWO) is highly appreciated. P.V. is indebted to the Fund for Scientific ResearchFlanders for research grants.

\section{References}

De Boer, W., Klein Gunnewiek, P. J. A., Lafeber, P., Janse, J. D., Spit, B. E. \& Woldendorp, J. W. (1998). Anti-fungal properties of chitinolytic dune soil bacteria. Soil Biol Biochem 30, 193-203.

De Boer, W., Klein Gunnewiek, P. J. A., Kowalchuk, G. A. \& Van Veen, J. A. (2001). Growth of chitinolytic dune soil $\beta$-subclass 
Proteobacteria in response to invading fungal hyphae. Appl Environ Microbiol 67, 3358-3362.

De Boer, W., Leveau, J. H. J., Kowalchuk, G. A., Klein Gunnewiek, P. J. A., Abeln, E. C. A., Figge, M. J., Sjollema, K., Janse, J. D. \& Van Veen, J. A. (2004). Collimonas fungivorans gen. nov., sp nov., a chitinolytic soil bacterium with the ability to grow on living fungal hyphae. Int J Syst Evol Microbiol 54, 857-864.

Ezaki, T., Hashimoto, Y. \& Yabuuchi, E. (1989). Fluorometric deoxyribonucleic acid-deoxyribonucleic acid hybridization in microdilution wells as an alternative to membrane-filter hybridization in which radioisotopes are used to determine genetic relatedness among bacterial strains. Int J Syst Bacteriol 39, 224-229.

Höppener-Ogawa, S., Leveau, J. H. J., Smant, W., van Veen, J. A. \& de Boer, W. (2007). Specific detection and real-time PCR quantification of potentially mycophagous bacteria belonging to the genus Collimonas in different soil ecosystems. Appl Environ Microbiol 73, 4191-4197.

Keys, C. J., Dare, D. J., Sutton, H., Wells, G., Lunt, M., McKenna, T., McDowall, M. \& Shah, H. N. (2004). Compilation of a MALDI-TOF mass spectral database for the rapid screening and characterisation of bacteria implicated in human infectious diseases. Infect Genet Evol 4, 221-242.

King, E. O., Ward, M. K. \& Rainey, D. E. (1954). Two simple media for the demonstration of pyocyanin and fluorescein. J Lab Clin Med 44, 301-307.
Marmur, J. (1961). A procedure for the isolation of deoxyribonucleic acid from microorganisms. J Mol Biol 3, 208-218.

Mesbah, M., Premachandran, U. \& Whitman, W. B. (1989). Precise measurement of the $\mathrm{G}+\mathrm{C}$ content of deoxyribonucleic acid by high-performance liquid chromatography. Int J Syst Bacteriol 39, 159-167.

Pot, B., Vandamme, P. \& Kersters, K. (1994). Analysis of electrophoretic whole-organism protein fingerprints. In Chemical Methods in Prokaryotic Systematics, pp. 493-521. Edited by M. Goodfellow \& A. G. O'Donnell. Chichester: Wiley.

Rademaker, J. L. W., Louws, F. J. \& de Bruijn, F. J. (1997). Characterization of the diversity of ecologically important microbes by rep-PCR genomic fingerprinting. In Molecular Microbial Ecology Manual, supplement 3, chapter 3.4.3, pp. 1-26. Dordrecht: Kluwer Academic.

Rosch, C. \& Bothe, H. (2005). Improved assessment of denitrifying, $\mathrm{N}_{2}$-fixing, and total-community bacteria by terminal restriction fragment length polymorphism analysis using multiple restriction enzymes. Appl Environ Microbiol 71, 2026-2035.

Willems, A., Doignon-Bourcier, F., Goris, J., Coopman, R., de Lajudie, P., De Vos, P. \& Gillis, M. (2001). DNA-DNA hybridization study of Bradyrhizobium strains. Int J Syst Evol Microbiol 51, 1315-1322. 